Association for Information Systems AIS Electronic Library (AISeL)

2000

\title{
Internet Adoption Barriers for Small Firms in the Netherlands
}

Rita Walczuch

University of Maastricht, r.walczuch@mw.unimaas.nl

Follow this and additional works at: http://aisel.aisnet.org/amcis2000

\section{Recommended Citation}

Walczuch, Rita, "Internet Adoption Barriers for Small Firms in the Netherlands" (2000). AMCIS 2000 Proceedings. 243.

http://aisel.aisnet.org/amcis2000/243

This material is brought to you by the Americas Conference on Information Systems (AMCIS) at AIS Electronic Library (AISeL). It has been accepted for inclusion in AMCIS 2000 Proceedings by an authorized administrator of AIS Electronic Library (AISeL). For more information, please contact elibrary@aisnet.org. 


\title{
Internet adoption barriers for small firms in the Netherlands
}

\author{
Rita Walczuch, Gert den Braven and Henriette Lundgren, International Institute of Infonomics, \\ Department of Management, University of Maastricht, Postbus 616, 6200MD Maastricht, The \\ Netherlands, Tel: +31-43-3883724, Fax: +31-43-3884893, r.walczuch@mw.unimaas.nl
}

\begin{abstract}
Small firms are not adopting the Internet with the same speed their larger brothers do. This despite the fact that Internet can offer a great deal of advantages to small firms. This study aims to explore several factors that influence small businesses in their choice of Internet use (e.g. benefits and barriers). The main barriers to Internet adoption and to developing a Web presences are simply the concern that the Internet or the Website would not lead to more efficiency or lower costs. However, the results show that a number of the benefits that Dutch small firms are deriving from their Websites can be described as "border-crossing". These results seem to confirm the "international" image of Dutch businesses, well aware of the small size of the local market and always searching for potential business opportunities abroad.
\end{abstract}

\section{Introduction $^{1}$}

Small firms are not adopting the Internet with the same speed their larger brothers do (Computerworld, 1998). This despite the fact that Internet can offer a great deal of advantages to small firms. Through Internet they can be visible 24 hours a day all around the world. Internet technology can be the basis for an intranet, or even an extranet. These issues and more used to be far too expensive for small firms. Kalakota \& Whinston (Kalakota and Whinston, p. 135) conclude: "as restrictions are dismantled, commercial use of the Internet is becoming more common. This is especially good for small businesses."

Small firms are vital in our economy, very often recognized as an economy growth engine (Brouthers, et al., 1998). They often occupy strategic positions, provide society with new products and contribute largely to total employment $(38,5 \%)$ (Economisch Instituut voor het Midden- en Kleinbedrijf, 1997). It is therefore important that the new information society will be embraced by the smaller firms as well, because it will eventually have an impact on their productivity, market access, and competitiveness.

\footnotetext{
${ }^{1}$ We would like to thank the reviewers of AMCIS
} 2000 for their valuable comments, which helped us to improve the quality of the paper.
This paper focuses on the use of the Internet by small firms, and more specifically small firms in the Netherlands. The central research question is:

\section{What are the benefits of and barriers to Internet use experienced by small firms in the Netherlands?}

When answering this question our attention will be on the following four sub questions:

- What are the benefits Dutch small firms derive from the Internet?

- In what ways do Dutch small firms use the Internet?

- To what extend do Dutch small firms use their own websites?

- What are the barriers obstructing Dutch small firms from (full) Internet usage?

A questionnaire, sent out to a little less than a thousand firms, was used as the method to answer these questions. This paper will first review current research on the issue and develop hypotheses, shortly describe the methodology used, give a summary of the results, and discuss these results.

\section{Small Firms and the Internet}

\section{Benefits of Internet use by small firms}

Poon \& Strom (1997), Abell \& Lim (1996), and Poon \& Swatman (1997) report empirical studies on how much benefit small firms actually derive from the Internet and in what way. Bloch et al. (1996) developed a framework which can be used to categorize the benefits into direct (new sales channels, direct savings and time to market) and indirect (product promotion, customer service, brand image, technological and organizational learning, customer relations and new business models) benefits.

However, not all of these benefits are perceived as being equally important by small firms. Poon \& Strom (1997) conclude that the savings and/or directs earnings small firms derive from the Internet are marginal. An interesting finding of Abell \& Lim's study (1996) was that small firms claim more benefits from Internet than larger ones. The benefits claimed most important were 
effectiveness in information gathering, and availability of expertise regardless of location. Poon \& Swatman (1997) come to the same conclusion. Their empirical results show that the largest benefits for small firms are speedy and timely access to information from Websites, and communication efficiency improvement.

In summary, direct benefits (e.g. lower costs for supply acquisition) can be characterized as relatively easy to quantify (Poon and Swatman, 1997). Indirect benefits on the other hand (e.g. improved company image) are much harder to quantify and their effect is to be felt more on the long term. An Internet Website clearly offers some potential costs saving and/or revenue enhancing capabilities. Research however has shown that so far savings or earnings directly from the Internet are marginal (Abell and Limm, 1996; Poon and Strom, 1997; Poon and Swatman, 1997). One may expect the same scenario for Dutch small businesses.

\section{$H_{1}:$ Small firms in the Netherlands obtain only indirect benefits from an Internet Website now or within a year.}

\section{Internet uses}

Up to now, two small-scale studies have been undertaken, which investigated the ways small companies use the Internet (Abell and Limm, 1996; Poon and Strom, 1997). The conclusion of these two studies show that small companies use the Internet primarily as a communications medium. E-mail is the dominant use in the content and context period of the electronic market place evolution (Block and Guptill, 1997). According to the Gartner Group's timetable, most enterprises are in the context period right now. Poon and Strom (1997, p.4) state that for their sample of firms "the ability to communicate, particularly with international customers or business partners without necessarily being worried about their whereabouts was convenient." The way of communicating over the Internet by these small firms was E-mail. One might therefore expect the same popularity of E-mail for Dutch small firms.

\section{$\mathrm{H}_{2}$ : The most popular way of using the Internet for small firms in the Netherlands is E-mail.}

\section{Websites}

Zwass (1996) structured electronic commerce into three categories: consumer-oriented commerce, businessto-business commerce, and intraorganizational business. The largest of these three categories will probably be business-to-business electronic commerce. Timmers (Timmers, 1998, p.3) states that although there might be several 100 millions of consumers on the Internet by the year 2000 "it is expected that business-to-business will constitute the larger part of electronic commerce." This prediction is supported by market research that concludes that the share of business-to-business commerce will rise from 66 per cent to 79 per cent in the period 1998-2002 (Automatiseringsgids, 1998). A Website does not have to be entirely oriented to one of these three segments. But, since the business-to-business segment is the largest segment of electronic commerce, one may expect that the largest part of all Websites is business-to-business oriented.

\section{$\mathrm{H}_{3}:$ The largest part of all Websites of small firms in the Netherlands is business-to-business oriented.}

\section{Barriers}

Market research studies focusing on issues and barriers for small business were conducted by Abell \& Lim (1996) and Purao \& Campbell (1998). Both found issues and barriers surrounding Internet access and use. Purao \& Campbell (1998) adopted an exploratory research strategy and held interviews with several small business owners, of which some were already on-line and some were not. Their main conclusions are that the primary barriers for firms in establishing a web presence "appear to be start up costs, unfamiliarity with the web and lack of guidance about how to start the process" (Purao and Campbell, 1998, p.327). The primary concern for firms that already had a web presence is security hazards.

The study of Abell \& Lim (1996) was aimed at firms already using the Internet. They also conclude that "fruitful use is being hampered by concerns over security" (Abell and Limm, 1996, p.8). They divided the security aspect in a lot of separate barriers of which "guarantee of message delivery" proved to be the most important issue.

\section{Reasons for not having Internet access}

Surprisingly little research has been conducted concerning non-Internet adoption. When considering the current state of Internet adoption by small businesses, this issue is obviously important. A report of the Dutch government, called "Nationaal Aktieplan Elektronische Snelweg (National Plan Electronic Highway)", claims that small and medium-sized enterprises feel that the costs for computer equipment are relatively high (BoozAllen\&Hamilton, 1997, p.7; Computable, 1998) say that the slow rate of adoption of new technologies by SMEs in Europe is closely linked to the "high investments necessary (relatively speaking for SMEs)". This leads to the hypothesis:

\section{$\mathrm{H}_{4}$ : The most important reason, for small firms in the Netherlands, for not having Internet access are the high costs.}




\section{Attitude towards Internet}

Measurement of attitude of non-adopters towards Internet seems important in further exploring reasons underlying non-adoption. Research on attitudes towards Internet has however been poorly developed. Brouthers, Andriessen \& Nicolaes (1998, p.136) conclude in a survey on strategic decision making by managers of small Dutch firms that "small firm managers tended to choose strategies based on their personal desires and backgrounds, as opposed to selecting the best-fit strategy based on rational analysis." Internet adoption can be regarded as a strategic decision. Since intuition and personal opinions play such a big role in small firm strategic decision making, it can be expected that small firms without Internet access tend to have a negative image of the Internet.

\section{$H_{5}:$ Small firms in the Netherlands without Internet access have a negative image of the Internet.}

\section{Reasons for not having an own Website}

Market research reports have indicated that Internet access does not automatically mean a company Website (Centraal Bureau voor de Statistiek, 1998). There seem to be significant barriers obstructing the development of a web presence. Purao and Campbell (1998, p.3) found that "the primary deterrents for small businesses in establishing a web presence appear to be start up costs, unfamiliarity with the web and lack of guidance about how to start the process." The deterrent obstructing the step from Internet access to an own Website therefore is the high cost envolvement. Constructing and maintaining an own Website is regarded as being too expensive.

\section{$H_{6}:$ The most important reason, for small firms in the Netherlands with Internet access, for not having their own Website are the high costs.}

\section{Concerns surrounding Internet use}

A potential source of trouble is the concern about security, which could lead to holding back from full use of the Internet. The issue may result from a bad image of Internet security brought to life in many frightening stories published in media. Old and new research confirms that security is the largest concern surrounding the Internet (Abell and Limm, 1996; Purao and Campbell, 1998; Zwaas, 1996). On the other hand, Abell and Lim (1996) found that the guarantee of message delivery was the main concern of the companies surveyed. Given the evident use of the Internet as a communication medium used by small firms (Poon and Strom, 1997), it seems logical that small firms are quite concerned on this aspect.

$\mathrm{H}_{7}:$ Guarantee of message delivery is the largest concern for small firms in the Netherlands.

\section{Methodology and Results}

\section{Methodology}

The research was carried out through a mail survey of small businesses in the Netherlands. A small business is, according to the criteria of the European Community, a firm with a maximum of 50 employees (Buhalis, 1996). In this thesis a restriction of having at least one employee was also chosen in order to exclude some organizational forms (e.g. holdings) that would not be suitable for the purposes of this study. No restriction based on type of industry was made. Each company in the sample was sent a four-page questionnaire.

The study, which was conducted in the February/March 1999, randomly selected 944 names of small businesses. The names were selected from a database of all 650000 small businesses kept at the Dutch Chamber of Commerce. Eliminating responses of firms with more than 50 employees and incorrect addresses amounted in a response rate of 16 percent. For all items the respondents were asked to indicate the status quo and their plans for the following year.

\section{Results}

By February 1999, 48 percent of Dutch small businesses already used the Internet. By February 2000, it was expected that 68 percent of Dutch small businesses are using the Internet. So, within one year, Internet usage is expected to increase by 20 percentage points. Twenty percent of Dutch small firms had their own Website in February 1999. This number is expected to increase to 32 percent in February 2000: an increase of 60 percent in one year (figure 1 in appendix A). A summary of the demographic profile of the responding firms is presented in table 1 in appendix A.

\section{$H_{1}:$ Small businesses in the Netherlands obtain only indirect benefits from an Internet Website now or within a year (not supported).}

The most important benefits Dutch small firms derive from their Websites now are the improvement of the company image and the disappearance of distance related barriers. Many benefits experienced by Dutch small firms seem to be "border-crossing": helping them to seek new markets and information abroad. None of the three possible direct benefits (lower costs acquiring supplies, increased productivity and increased sales) were of significant importance for the year 1999. In contrast, one possible direct benefit, "increased sales" has a significantly high mean for the year 2000 and can therefore be described as a direct benefit next year. This is a remarkable outcome since previous research showed that direct benefits gained from a Website are marginal and circumstantial. Hypothesis 1 can thus be rejected. No 
benefits were achieved that concerned suppliers (e.g. better service end delivery by suppliers). Given the obvious opportunities there, it is evident that that particular part of e-commerce is underdeveloped in the Dutch small business community (table 2 in appendix A).

\section{$\mathrm{H}_{2}$ : The most popular way of using the Internet for small firms in the Netherlands is E-mail (supported).}

In order to test hypothesis 2, respondents with Internet access had to indicate in which ways they are using the Internet. Practically all companies with access to Internet use E-mail for external communication (91 percent). It should be noted that most firms use E-mail only for external communication, not for internal communication (25 percent). The other main uses are searching for Webpage addresses (79 percent) and randomly looking for information (76 percent). More advanced uses, as obtaining information from suppliers (57 percent), offering information to consumers (32 percent), and contact with governmental agencies ( 28 percent), were used on a broader scale than might have been expected. Offering information to customers, sending purchase orders to suppliers, and receiving orders from customers are the major areas for growth over the next year (respectively 18, 17, and 16 percentage points growth). Uses as voice/video conferencing and placing job vacancies, which are hardly used momentarily, also show high growth potential. One can conclude that, although the Internet is mostly used for less advanced communication purposes momentarily, more advanced uses are already practiced and their usage factor is bound to grow considerably in the near future (table 3 in appendix A).

\section{$H_{3}:$ The largest part of all Websites of small firms in the Netherlands is business-to-business oriented (not supported).}

Respondents were asked for the relative proportions of their Website oriented towards the consumer, "businessto-business", or the own organization. When considering the form and content of the small firms' Websites, the informational and communicative aspects of the medium Internet are most used. Practically all Websites (97 percent) have an E-mail address end respectively 90 and 86 percent of the Websites provide rational information, and promote the company and/or its products. A little less than one third (31 percent) of all Websites offers the opportunity to order electronically and 21 percent provides customer service on its Website. None of the firms in the sample had an Intranet or Extranet (tables 4 and 5 in appendix A). The company Website is hardly integrated into the company processes. Hypothesis 3 could therefore be rejected.

\section{$\mathrm{H}_{4}$ : The most important reason for small firms in the Netherlands, for not having Internet access are the high costs (not supported).}

Hypothesis 4 was tested with several statements, which gave possible reasons why firms would not have access to the Internet. These statements could then be described as real barriers obstructing Internet access. Different reasons for not having Internet access were formulated, of which two concerned the costs involved: "too expensive with regard to computer equipment" and "too expensive with regard to telecommunication costs." It turned out that these two reasons are not significantly obstructing firms from getting Internet access. In fact, the only two significant reasons are that Internet access "does not lead to more efficiency or lower costs" and a "lack of time." Hypothesis 4 can therefore be rejected (table 6 in appendix A).

\section{$\mathrm{H}_{5}:$ Small firms in the Netherlands without Internet access have a negative image of the Internet (not supported).}

Seven statements were formulated to the image of the Internet. Respondents were firms without Internet access or own Website. The findings of this part indicate that there is no significant negative attitude towards the Internet. The statement "not suitable for my company" attained a significant level, which does not imply a negative attitude towards the Internet in general. On this basis, hypothesis 5 can be rejected. Interestingly, these firms still have a rather positive image of the Internet (table 7 in appendix A).

\section{$H_{6}:$ The most important reason for Dutch small companies with Internet access for not having their own Website are the high costs (not supported).}

In order to test this hypothesis, companies could state their opinion about the barriers obstructing an own Website. The result shows that the two factors "does not lead to more efficiency or lower costs" and "does not lead to more sales" are statistically significant in this context. The statement that an Internet Website is "too expensive" was not significant (table 8 in appendix A). This evidence leads to a rejection of hypothesis 6 .

\section{$H_{7}:$ Guarantee of message delivery is the largest concern for small firms in the Netherlands (not supported).}

For this hypothesis issues surrounding the Internet were researched. The following four issues have significantly large means and can therefore be described as concerns: "security of financial information transmitted 
over the Internet", "enforcement of contracts concluded over the Internet", "unauthorized access internal networks", and "interception messages by third parties." These findings are especially interesting since they show that security still is an Internet issue of major concern. In contrast, the issue "guarantee of message delivery" does not reach a significant level (table 9 in appendix A). It is therefore evident that it is not the largest concern for small firms, which leads to the rejection of hypothesis 7 .

\section{Conclusion and Discussion}

The study presented in this paper provides evidence that small businesses are indeed catching on to the advantages provided by the Internet. However, pragmatic as most small business owners are, the short-term benefits must be readily apparent to make a significant investment in new technology and know-how.

This study shows that a number of the benefits that Dutch small firms are deriving, or will derive within a year, from their Websites can be described as "bordercrossing" (disappearance of distance related barriers now, continuous advertising all around the world next year). These results seem to confirm the "international" image of Dutch businesses, well aware of the small size of the local market and always searching for potential business opportunities abroad. Brouthers, Andriessen, and Nicolaes (1998) found that almost one-fourth of Dutch small business are aggressively pursuing new markets or new products. It seems that the Internet is one of the tools in this quest.

It was also interesting to see that more advanced uses as obtaining information from suppliers, offering information to consumers, and contact with governmental agencies were used on a broader scale than might have been expected. The most technically advanced uses, as receiving customer orders and voice/video conferencing, were however among the least used. Promising was the high growth potential these uses showed (expected growth of respectively 17 and 8 percentage points over a year). It seems justified to conclude that although small Dutch businesses use the Internet mostly for less advanced communication purposes momentarily, more advanced uses are already in use and their usage factor is bound to grow considerably in the near future.

One result of this study is that small Dutch firms' Websites are not being exploited to the full potential that electronic commerce technology can offer nowadays. Important in this respect is that the small firms' Websites are hardly integrated into the company processes. Again the informational aspect of the Internet is mostly used. Most Websites are not constructed to sell, to search for suppliers, or to be a part of an intranet or extranet. The technology of today does provide these opportunities and when seizing the fruits of electronic commerce in the future, Websites need to have more content to attract buyers (Block and Guptill, 1997). But, likewise with the results of this study in mind one cannot state that small Dutch firms with a Website only show their face on the Internet and then it stops. Already today a little less than one third of all Websites offer the opportunity to order electronically and 21 percent provides customer service on its Website. These numbers show that part of the Websites are much more than electronic flyers. And, as already mentioned, the results of this study also show that one perceived benefit of a Website is increased sales. Also given the expected large growth of the Dutch electronic commerce market over the next years (Sanders, 1998), one may expect an equivalent maturation of small firms' Websites.

The main barriers to Internet adoption and to developing a Web presences are simply the concern that the Internet or the Website would not lead to more efficiency or lower costs and the feeling that the Internet or a Website is not suitable for a particular business. In other words, small businesses do not see any direct benefits in it, and therefore do not want to invest time and money in an Internet presence. Small businesses show their pragmatic way of doing business in that investments should, in the short term, make money or lower costs. Interestingly, the small businesses already having a Website claim in this survey that one of the benefits of their Website is increased sales. For policy makers wanting to increase the percentage of small businesses making use of the Internet, the best strategy of convincing small business owners of the benefits of electronic commerce is through showing concrete examples. In this respect one can think of showcases of similar small firms that have achieved higher sales and/or cost reductions through the use of the Internet.

This study has shown that many Dutch small businesses are well on their way to use the Internet to reach new markets. The Dutch trader's culture has found its way into the Internet.

A similar study across different countries and cultures would be a good extension of this study, and could therefore become the theme of future research. Studying only Dutch business and their propensity of getting onto the web has a limited number of benefits. Thus, the establishment of a sound basis for comparison across different countries would probably lead us to particular attributes, i.e. cultural, legislative and others. These attributes could then serve as a guide for small businesses to get onto the web.

\section{References}

Abell, W. and Limm, L. "Business Use of the Internet in New Zealand: an Exploratory Study," http://www.scu.edu.au/sponsored/ ausweb96 / business/abell/paper.html, (Current Jan. 15, 1999). 
Automatiseringsgids "IDC Waarschuwt: Wacht Niet met E-Handel,", September 11, 1998, pp. 2.

Block, J. and Guptill, B. "Electronic Marketplace Strategies: Visions vs. Reality," Gartner Group, June 13, 1997.

Booz-Allen\&Hamilton "G7 Global Marketplace for SME's," Proceedings of the First Annual Conference, Bonn, 1997.

Brouthers, K.D., Andriessen, F. and Nicolaes, I. "Driving Blind: Strategic Deciosion-Making in Small Companies," Long Range Planning (31:10), 1998, pp. 130-138.

Buhalis, D. "Enhancing the Competitiveness of Small and Medium-Sized Tourism Enterprises," International Journal of Electronic Commerce (6:1), 1996, pp. 1-7.

Centraal Bureau voor de Statistiek "Een op de Drie Bedrijven Actief op Internet," Persbericht Centraal Bureau voor de Statistiek, May 8, 1998.

Computable "Nederlander Gebruikt E-Snelweg te Weinig," (:16), April 17, 1998, pp. 1.

Computerworld "Commerce by Numbers," http://www.computerworld.com/home/Emmerce.nsf/all/re v, (Current Jan 15, 1999).

Economisch Instituut voor het Midden- en Kleinbedrijf Het Midden- an Kleinbedrijf in de Nationale Economie, 1997.

Poon, S. and Strom, J. "Small Businesses Use of the Internet: Some Realities," Proceedings of the Association for Information Systems Americas Conference, 1997.

Poon, S. and Swatman, P. "The Internet for Small Businesses: An Enabling Infrastructure," Proceedings of the Fifth Internet Society Conference, Chon K., Hawaii, 1997, pp. 221-231.

Purao, S. and Campbell, B. "Critical Concerns for Small Business Electronic Commerce: Some Reflections Based on Interviews of Small Business Owners," Proceedings of the Association for Information Systems Americas Conference, 1998, pp. 325-327.

Sanders, R. "Economische Handel Breekt Pas na 2000 Door," Computable, (:51), December 18, 1998, pp. 9.

Timmers, P. "Business Models for Electronic Markets," Electronic Markets (8:2), 1998, pp. 3-8.
Zwaas, V. "Electronic Commerce: Structures and Issues," International Journal of Electronic Commerce (1), 1996, pp. 3-23.

\section{Appendix A}

Figure 1. Division of Internet use February 1999 and 2000

\section{Division February 1999}

\section{Probable Division February 2000}

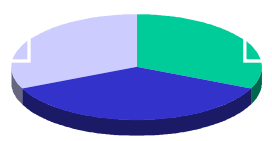

Table 1. Sample characteristics

\begin{tabular}{|l|l|l|}
\hline & N & Average \\
\hline Turnover (guilders) & 62 & fl. 1.471.489 \\
\hline Number of employees & 128 & 6,4 \\
\hline Company age (years) & 135 & 16,8 \\
\hline $\begin{array}{l}\text { Percentage of revenue } \\
\text { through export (\%) }\end{array}$ & 108 & 11,2 \\
\hline $\begin{array}{l}\text { Percentage of purchases } \\
\text { through import (\%) }\end{array}$ & 106 & 12,7 \\
\hline $\begin{array}{l}\text { Percentage of sales over } \\
\text { Internet (\%) }\end{array}$ & 100 & 0,3 \\
\hline $\begin{array}{l}\text { Percentage of purchases over } \\
\text { Internet (\%) }\end{array}$ & 101 & 0,8 \\
\hline $\begin{array}{l}\text { Degree to which ICT- } \\
\text { activities are outsourced }\end{array}$ & 124 & 1,54 \\
\hline Months of Internet access & 65 & 19,3 \\
\hline $\begin{array}{l}\text { Degree to which Website is } \\
\text { integrated within company } \\
\text { processes }\end{array}$ & 28 & 1,39 \\
\hline
\end{tabular}

a. Likert-scale ranging from "no outsourcing" (1) to "total outsourcing" (5)

b. Likert-scale ranging from "no integration" (1) to "total integration" (5) 
Table 2. Perceived benefits

One sample t-test, test value $=3^{\mathrm{a}}$

\begin{tabular}{|c|c|c|c|c|c|}
\hline & & Now & & Within & year \\
\hline Perceived benefits & $\mathrm{N}$ & Mean & S.D. & Mean & S.D. \\
\hline $\begin{array}{l}\text { Distance related barriers } \\
\text { disappear }\end{array}$ & 25 & $3,52 * *$ & 1,19 & 3,46 & 1,35 \\
\hline $\begin{array}{l}\text { Improvement company } \\
\text { image }\end{array}$ & 27 & $3,41 *$ & 1,19 & $\begin{array}{l}3,96 * * \\
* \\
\end{array}$ & ,72 \\
\hline $\begin{array}{l}\text { Continuous advertising all } \\
\text { around the world }\end{array}$ & 25 & 3,32 & 1,35 & $3,59 *$ & 1,38 \\
\hline Increased sales & 26 & 3,31 & 1,26 & $3,54 *$ & 1,32 \\
\hline $\begin{array}{l}\text { Effectiveness in collecting } \\
\text { information }\end{array}$ & 25 & 3,24 & 1,42 & $3,57 * *$ & 1,12 \\
\hline More customer service & 25 & 3,20 & 1,35 & 3,31 & 1,29 \\
\hline $\begin{array}{l}\text { Increased customer } \\
\text { satisfaction }\end{array}$ & 26 & 3,08 & 1,39 & \begin{tabular}{|l}
$3,64 * *$ \\
$*$
\end{tabular} & 1,00 \\
\hline $\begin{array}{l}\text { Possibility reaching } \\
\text { international markets }\end{array}$ & 26 & 3,04 & 1,46 & 3,17 & 1,40 \\
\hline \begin{tabular}{|l} 
Better consciousness \\
"business environment"
\end{tabular} & 24 & 2,92 & 1,53 & 2,62 & 1,47 \\
\hline $\begin{array}{l}\text { Availability of knowledge } \\
\text { regardless location }\end{array}$ & 24 & 2,92 & 1,47 & 2,64 & 1,47 \\
\hline $\begin{array}{l}\text { Better information on } \\
\text { your customers }\end{array}$ & 24 & $\begin{array}{l}2,13 * * \\
* \\
\end{array}$ & 1,39 & 2,83 & 1,55 \\
\hline Increased productivity & 24 & $\begin{array}{l}1,96 * * \\
*\end{array}$ & 1,40 & $2,00 * *$ & 1,34 \\
\hline $\begin{array}{l}\text { Better support and service } \\
\text { by suppliers }\end{array}$ & 23 & $\begin{array}{l}1,57 * * \\
* \\
\end{array}$ & ,95 & $\begin{array}{l}1,55^{* *} \\
* \\
\end{array}$ & 1,06 \\
\hline $\begin{array}{l}\text { Faster and/or more } \\
\text { flexible delivery suppliers }\end{array}$ & 23 & $\begin{array}{l}1,43 * * \\
* \\
\end{array}$ & ,79 & $\begin{array}{l}1,50 * * \\
* \\
\end{array}$ & 1,06 \\
\hline $\begin{array}{l}\text { Lower costs acquiring } \\
\text { supplies }\end{array}$ & 23 & $\begin{array}{l}1,30 * * \\
*\end{array}$ & ,64 & $\begin{array}{l}1,41 * * \\
*\end{array}$ & 1,01 \\
\hline
\end{tabular}

$\mathrm{a} * * * \mathrm{p}<0.01, * * \mathrm{p}<0.05, * \mathrm{p}<0.10$.
Table 3. Ways of using the Internet

\begin{tabular}{|c|c|c|c|}
\hline & \begin{tabular}{|l|} 
Usage \\
percentage \\
$(\%)$
\end{tabular} & \begin{tabular}{|l|}
$\begin{array}{l}\text { Probable } \\
\text { usage next } \\
\text { year }(\%)\end{array}$ \\
\end{tabular} & \begin{tabular}{|l} 
Percentage \\
points \\
growth \\
\end{tabular} \\
\hline $\begin{array}{l}\text { 1. External } \\
\text { communication (E- } \\
\text { mail) }\end{array}$ & 91 & 94 & 03 \\
\hline $\begin{array}{l}\text { 2. Searching for } \\
\text { Webpage addresses }\end{array}$ & \begin{tabular}{|l|l}
79 \\
\end{tabular} & 81 & 02 \\
\hline $\begin{array}{l}\text { 3. Randomly } \\
\text { looking for } \\
\text { information }\end{array}$ & 76 & 81 & 05 \\
\hline $\begin{array}{l}\text { 4. Obtaining } \\
\text { information from } \\
\text { suppliers }\end{array}$ & \begin{tabular}{|l|l}
57 \\
\end{tabular} & 68 & \begin{tabular}{|l|}
11 \\
\end{tabular} \\
\hline $\begin{array}{l}\text { 5. Offering } \\
\text { information to } \\
\text { consumers }\end{array}$ & 32 & 50 & 18 \\
\hline $\begin{array}{l}\text { 6. Contact with } \\
\text { governmental } \\
\text { agencies }\end{array}$ & 28 & 39 & 11 \\
\hline $\begin{array}{l}\text { 7. Internal } \\
\text { communication }\end{array}$ & 25 & 28 & 03 \\
\hline $\begin{array}{l}\text { 8. R\&D and } \\
\text { sharing of } \\
\text { information and } \\
\text { software }\end{array}$ & \begin{tabular}{|l|}
19 \\
\end{tabular} & 22 & 03 \\
\hline $\begin{array}{l}\text { 9. To be seen at } \\
\text { the foreground of } \\
\text { modern technology }\end{array}$ & 18 & 25 & 07 \\
\hline $\begin{array}{l}10 . \text { Sending } \\
\text { purchase orders to } \\
\text { suppliers }\end{array}$ & \begin{tabular}{|l|}
18 \\
\end{tabular} & 34 & 16 \\
\hline $\begin{array}{l}\text { 11. Product- and } \\
\text { market research }\end{array}$ & \begin{tabular}{|l|l|}
18 \\
\end{tabular} & 26 & 08 \\
\hline $\begin{array}{l}\text { 12. Receiving } \\
\text { orders from } \\
\text { customers }\end{array}$ & 12 & 29 & 17 \\
\hline $\begin{array}{l}\text { 13. Voice/video } \\
\text { conferencing }\end{array}$ & \begin{tabular}{|l|}
01 \\
\end{tabular} & 09 & 08 \\
\hline $\begin{array}{l}\text { 14. Placing job } \\
\text { vacancies }\end{array}$ & $\mid 00$ & 10 & 10 \\
\hline
\end{tabular}

Table 4. Applications on Website/possibilities of using

Website

\begin{tabular}{|l|l|}
\hline & $\begin{array}{l}\text { Percentage of } \\
\text { companies (\%) }\end{array}$ \\
\hline E-mail address & 97 \\
\hline To provide rational information & 90 \\
\hline To promote company and/or products & 86 \\
\hline To order & 31 \\
\hline Customer service & 21 \\
\hline To search for suppliers & 10 \\
\hline To pay & 07 \\
\hline Built-in security & 07 \\
\hline To offer job vacancies & 03 \\
\hline Information for personnel (intranet) & 00 \\
\hline Extranet & 00 \\
\hline
\end{tabular}


Table 5. Division of Website

\begin{tabular}{|l|l|l|l|}
\hline & Mean & $\begin{array}{l}\text { Std } \\
\text { Deviation }\end{array}$ & Range \\
\hline $\begin{array}{l}\text { Percentage site consumer- } \\
\text { oriented }\end{array}$ & 47,41 & 42,44 & 100,00 \\
\hline $\begin{array}{l}\text { Percentage site "business-to- } \\
\text { business" -oriented }\end{array}$ & 50,86 & 41,45 & 100,00 \\
\hline $\begin{array}{l}\text { Percentage site oriented at own } \\
\text { organisation }\end{array}$ & 1,72 & 9,28 & 50,00 \\
\hline
\end{tabular}

Table 6. Reasons for not having Internet access

One sample t-test, test value $=3^{\mathrm{a}}$

\begin{tabular}{|c|c|c|c|c|c|c|c|}
\hline \multirow[b]{2}{*}{ Variable } & \multicolumn{3}{|c|}{ Whole sample } & \multicolumn{2}{|c|}{$\begin{array}{l}\text { Firms with } \\
\text { Internet } \\
\text { access } \\
\text { within a } \\
\text { year }\end{array}$} & \multicolumn{2}{|c|}{$\begin{array}{l}\text { Firms with } \\
\text { no Internet } \\
\text { access within } \\
\text { a year }\end{array}$} \\
\hline & $\mathbf{N}$ & Mean & S.D. & Mean & S.D. & Mean & S.D. \\
\hline Lack of time & 61 & $\begin{array}{l}3,64 \\
* *\end{array}$ & 1,38 & 3,30 & 1,17 & $3,84 * * *$ & 1,51 \\
\hline $\begin{array}{l}\text { Does not lead to } \\
\text { more efficiency or } \\
\text { lower costs }\end{array}$ & 56 & $\begin{array}{l}3,63 \\
* *\end{array}$ & 1,46 & 2,80 & 1,44 & $4,29 * * *$ & 1,10 \\
\hline $\begin{array}{l}\text { Too expensive } \\
\text { with regard to } \\
\text { telecommunication } \\
\text { costs }\end{array}$ & 55 & 3,20 & 1,45 & 3,00 & 1,44 & 3,38 & 1,45 \\
\hline $\begin{array}{l}\text { Technically too } \\
\text { complicated }\end{array}$ & 55 & 2,93 & 1,49 & $2,44^{*}$ & 1,42 & 3,28 & 1,44 \\
\hline $\begin{array}{l}\text { Too expensive } \\
\text { with regard to } \\
\text { computer } \\
\text { equipment }\end{array}$ & 54 & 2,91 & 1,35 & $2,46^{*}$ & 1,35 & 3,27 & 1,26 \\
\hline Insecure & 50 & $\begin{array}{l}2,58 \\
* *\end{array}$ & 1,43 & 2,75 & 1,42 & $2,42 *$ & 1,45 \\
\hline $\begin{array}{l}\text { Too slow when } \\
\text { using }\end{array}$ & 49 & $\begin{array}{l}2,45 \\
* * *\end{array}$ & 1,37 & 2,65 & 1,40 & $2,27 * *$ & 1,34 \\
\hline $\begin{array}{l}\text { Possible use for } \\
\text { unintended } \\
\text { purposes } \\
\text { personnel }\end{array}$ & 50 & $\begin{array}{l}2,24 \\
* * *\end{array}$ & 1,45 & $\begin{array}{l}2,25 \\
* *\end{array}$ & 1,42 & $2,23 * *$ & 1,50 \\
\hline
\end{tabular}

$\mathrm{a} * * * \mathrm{p}<0.01, * * \mathrm{p}<0.05, * \mathrm{p}<0.10$.
Table 7. Attitude towards Internet

One sample t-test, test value $=3^{\mathrm{a}, \mathrm{b}}$

\begin{tabular}{|c|c|c|c|c|c|c|c|}
\hline \multirow[b]{2}{*}{\begin{tabular}{|l|} 
Variable \\
\end{tabular}} & \multicolumn{3}{|c|}{ Whole sample } & \multicolumn{2}{|c|}{$\begin{array}{l}\text { Firms with } \\
\text { Internet } \\
\text { access within } \\
\text { a year }\end{array}$} & \multicolumn{2}{|c|}{$\begin{array}{l}\text { Firms with } \\
\text { no Internet } \\
\text { access within } \\
\text { a year }\end{array}$} \\
\hline & & Mean & S.D. & Mean & S.D. & Mean & S.D. \\
\hline $\begin{array}{l}\text { Not suitable } \\
\text { for my } \\
\text { company }\end{array}$ & 63 & 3,30 & 1,52 & $2,42 *$ & 1,27 & $\begin{array}{l}3,89 \\
* * *\end{array}$ & 1,37 \\
\hline $\begin{array}{l}\text { Only new } \\
\text { communicat } \\
\text { ion medium }\end{array}$ & 60 & 3,15 & 1,45 & 3,22 & 1,40 & 3,15 & 1,52 \\
\hline Rage & 60 & 2,85 & 1,53 & 2,56 & 1,40 & 3,09 & 1,61 \\
\hline $\begin{array}{l}\text { The future } \\
\text { for } \\
\text { conducting } \\
\text { business }(\mathrm{R})\end{array}$ & 57 & 2,70 & 1,46 & $\begin{array}{l}2,23 * \\
* *\end{array}$ & 1,24 & 3,10 & 1,54 \\
\hline $\begin{array}{l}\text { No place for } \\
\text { trade }\end{array}$ & 54 & $\begin{array}{l}2,31 \\
* * *\end{array}$ & 1,21 & $2,31 *$ & 1,26 & $\begin{array}{l}2,32 \\
* * *\end{array}$ & 1,19 \\
\hline $\begin{array}{l}\text { Suitable for } \\
\text { promotion } \\
\text { company } \\
\text { and } \\
\text { products }(\mathrm{R})\end{array}$ & 59 & $\begin{array}{l}2,29 \\
* * *\end{array}$ & 1,00 & $\begin{array}{l}1,93 * \\
* *\end{array}$ &, 83 & $\begin{array}{l}2,59 \\
* *\end{array}$ & 1,04 \\
\hline $\begin{array}{l}\text { Only for } \\
\text { technicians }\end{array}$ & 55 & $\begin{array}{l}1,87 \\
* * *\end{array}$ & 1,02 & $\begin{array}{l}1,81 * \\
* *\end{array}$ & 1,02 & $\begin{array}{l}1,93 * \\
* *\end{array}$ & 1,03 \\
\hline
\end{tabular}

$\mathrm{a} * * * \mathrm{p}<0.01, * * \mathrm{p}<0.05, * \mathrm{p}<0.10$.

b An (R) indicates that these items are reverse coded. The questions are recoded in the following way:

$1=5,2=4,3=3,4=2,5=1$.

Table 8. Reasons for not having own Website

One sample t-test, test value $=3^{\mathrm{a}}$

\begin{tabular}{|c|c|c|c|c|c|c|c|}
\hline \multirow[b]{2}{*}{ Variable } & \multicolumn{3}{|c|}{ Whole sample } & \multicolumn{2}{|c|}{$\begin{array}{l}\text { Firms with } \\
\text { Internet } \\
\text { Website } \\
\text { within a } \\
\text { year }\end{array}$} & \multicolumn{2}{|c|}{$\begin{array}{l}\text { Firms with } \\
\text { no Internet } \\
\text { Website } \\
\text { within a } \\
\text { year }\end{array}$} \\
\hline & $\mathbf{N}$ & Mean & S.D. & Mean & S.D. & Mean & S.D. \\
\hline $\begin{array}{l}\text { Does not lead to } \\
\text { more efficiency } \\
\text { or lower costs }\end{array}$ & 35 & $\begin{array}{l}3,66 \\
* * *\end{array}$ & 1,41 & 3,13 & 1,59 & $\begin{array}{l}4,15 \\
* * *\end{array}$ & 1,09 \\
\hline $\begin{array}{l}\text { Does not lead to } \\
\text { more sales }\end{array}$ & 39 & $\begin{array}{l}3,51 \\
* *\end{array}$ & 1,41 & 2,57 & 1,36 & $\begin{array}{l}4,04 \\
* * *\end{array}$ & 1,20 \\
\hline Lack of time & 37 & 3,24 & 1,69 & $\begin{array}{l}3,94 \\
* *\end{array}$ & 1,56 & 2,76 & 1,64 \\
\hline Too expensive & 36 & 2,78 & 1,50 & 2,69 & 1,58 & 2,95 & 1,50 \\
\hline $\begin{array}{l}\text { Technically too } \\
\text { complicated }\end{array}$ & 36 & $\begin{array}{l}2,42 \\
* *\end{array}$ & 1,30 & $\begin{array}{l}2,19 \\
* *\end{array}$ & 1,22 & 2,71 & 1,42 \\
\hline $\begin{array}{l}\text { Too few other } \\
\text { users }\end{array}$ & 33 & $\begin{array}{l}2,42 \\
* *\end{array}$ & 1,28 & $\begin{array}{l}1,93 \\
* * *\end{array}$ & 1,10 & 2,83 & 1,29 \\
\hline $\begin{array}{l}\text { Unclear } \\
\text { regarding law }\end{array}$ & 35 & $\begin{array}{l}2,26 \\
* * *\end{array}$ & 1,34 & $\begin{array}{l}2,19 \\
* *\end{array}$ & 1,38 & 2,45 & 1,43 \\
\hline Insecure & 33 & $\begin{array}{l}2,12 \\
* * *\end{array}$ & 1,22 & $\begin{array}{l}2,20 \\
* *\end{array}$ & 1,42 & $\begin{array}{l}2,06 \\
* * *\end{array}$ & 1,06 \\
\hline $\begin{array}{l}\text { Never thought } \\
\text { about it }\end{array}$ & 33 & $\begin{array}{l}1,88 \\
* * *\end{array}$ & 1,22 & $\begin{array}{l}1,60 \\
* * *\end{array}$ & 1,18 & $\begin{array}{l}2,11 \\
* * *\end{array}$ & 1,23 \\
\hline
\end{tabular}

$\mathrm{a} * * * \mathrm{p}<0.01, * * \mathrm{p}<0.05, * \mathrm{p}<0.10$. 
Table 9. Degree of concern regarding issues surrounding

Internet

One sample t-test, test value $=3^{\mathrm{a}}$

\begin{tabular}{|l|l|l|l|}
\hline Issues & $\mathrm{N}$ & Mean & S.D. \\
\hline $\begin{array}{l}\text { Security of financial } \\
\text { information transmitted } \\
\text { over Internet }\end{array}$ & 118 & $3,72^{* * *}$ & 1,30 \\
\hline $\begin{array}{l}\text { Enforcement of } \\
\text { contracts concluded } \\
\text { over the Internet }\end{array}$ & 113 & $3,48^{* * *}$ & 1,27 \\
\hline $\begin{array}{l}\text { Unauthorised access } \\
\text { internal networks }\end{array}$ & 116 & $3,31^{* *}$ & 1,33 \\
\hline $\begin{array}{l}\text { Interception messages } \\
\text { by third parties }\end{array}$ & 121 & $3,30^{* *}$ & 1,40 \\
\hline $\begin{array}{l}\text { Uncertainty regarding } \\
\text { authenticity messages }\end{array}$ & 121 & 2,99 & 1,38 \\
\hline $\begin{array}{l}\text { Lower productivity } \\
\text { because of improper use } \\
\text { personnel }\end{array}$ & 116 & $2,74^{* *}$ & 1,31 \\
\hline $\begin{array}{l}\text { Larger chance fraud } \\
\text { personnel }\end{array}$ & 113 & $2,61^{* * *}$ & 1,28 \\
\hline $\begin{array}{l}\text { User-friendliness } \\
\text { Internet }\end{array}$ & 117 & $2,60^{* * *}$ & 1,20 \\
\hline $\begin{array}{l}\text { Guarantee of message } \\
\text { delivery }\end{array}$ & 118 & $2,26^{* * *}$ & 1,15 \\
\hline Too few other users & 111 & $2,26^{* * *}$ & 1,13 \\
\hline
\end{tabular}

$\mathrm{a} * * * \mathrm{p}<0.01, * * \mathrm{p}<0.05, * \mathrm{p}<0.10$. 